\title{
Savosavo body part terminology
}

\author{
Claudia Wegener
}

Max Planck Institute for Psycholinguistics, Postbus 310, 6500 AH Nijmegen, The Netherlands

\begin{abstract}
This paper provides a description of body part terminology used in Savosavo, a Papuan language of the Solomon Islands. The first part of the paper lists the known terms and discusses their meanings. This is followed by an analysis of their structural properties. Finally, the paper discusses partonomic relations in Savosavo and argues that it is difficult to structure the body part terminology hierarchically, because there is no linguistic evidence for part-whole relations between body parts. (C) 2005 Elsevier Ltd. All rights reserved.
\end{abstract}

Keywords: Savosavo; Papuan languages; Austronesian; Body part terms; Partonomy; Meronymy; Semantic fields

\section{Introduction}

\subsection{The language and its speakers}

Savosavo is one of the few Papuan (i.e., non-Austronesian) languages spoken in the Solomon Islands. There are about 2500 speakers, most of them living on Savo Island in the Central Province. Savo Island is a volcanic island with a diameter of roughly $5 \mathrm{~km}$. The people on Savo live in small villages along the beach and have gardens on the slope of the volcano. There they grow vegetables (e.g., tomatoes, cucumbers, beans and cabbage) and tubers (e.g., kumara, yam and taro). Fish from the sea, poultry and occasionally pig meat are also important parts of their diet.

Savosavo is unrelated to its neighbours, which belong to the Oceanic branch of the Austronesian language family, namely the North-West Solomonic languages, belonging to the

E-mail address: claudia.wegener@mpi.nl 
Meso-Melanesian Cluster, and the South-East Solomonic family (Ross, 1988). As speakers of a Papuan language in an area surrounded by Oceanic-speaking people, Savosavo speakers live in a complex linguistic setting. They are typically multilingual in at least two or three languages (see Todd, 1977, p. 806). Solomon Islands Pijin, the lingua franca of the Solomon Islands, is spoken by all people on Savo. Children attending school also learn English, which is the official language of instruction, although it is rarely used on Savo. In addition almost all Savosavo speakers are fluent in one or more neighbouring Oceanic languages, having close contact and sometimes family ties with members of Oceanic-speaking communities. Those who relocate to Savo (typically due to marriage) rarely learn Savosavo because they can communicate in Solomon Islands Pijin and even in their native language; furthermore Savosavo is very different from their native Oceanic languages, giving it a reputation in the Solomons as a difficult language to learn. As a result of this there are some villages on Savo where two Oceanic languages of neighbouring islands are spoken almost exclusively, Gela (South-East Solomonic, spoken on Gela) in the northeast, and Ghari (South-East Solomonic, spoken on Guadalcanal) in the south of Savo Island.

Typologically, Savosavo is a verb-final language; modifiers in a noun phrase are prenominal; the possessor precedes the possessed item. Verbs do not agree with their subjects, but only with their objects. As is common in Papuan languages (Foley, 1986; Dunn et al., 2002; Terrill, 2002), Savosavo has a nominal classification system in the form of two genders, masculine and feminine. For nouns referring to humans and higher animate beings class membership is determined by sex. All other nouns are by default masculine, but can temporarily be assigned to the feminine class, e.g., for diminutive purposes (see Wegener, in preparation). Due to the fact that Savosavo has been surrounded by and in contact with several Oceanic languages for a long period of time many vocabulary items (including some body part terms) as well as grammatical features have been borrowed from these languages.

\subsection{The data}

This description of body part terms in Savosavo is based on material collected by the author during six months of fieldwork. With regard to the body part terms discussed in this paper two kinds of data play an important role: one is data collected on the basis of the questionnaire developed by Enfield (this volume), the other is data collected using the Body Colouring Task designed by van Staden and Majid (this volume). In the Body Colouring Task native speakers of Savosavo were asked to colour in the corresponding body parts when given a body part term. Four men and four women ranging in age from 14 to 60 years participated in this task, in which eighteen Savosavo body part terms were used.

\section{Inventory of body parts}

In this section the collected Savosavo body part terms are given and their meanings are discussed. They are presented in tables consisting of three columns; the Savosavo terms are listed in the first column, the second column gives an approximate English translation, and the third column provides, if necessary, explanations and/or glosses (a question mark indicates that the meaning of a word is unclear at present). 
This is a solely synchronic analysis of the body part terms in Savosavo; a complete diachronic analysis is not possible without more research. Comparative data for the languages of the Solomon Islands were obtained from Tryon and Hackman (1983) and a 200 item wordlist of Gela (South-East Solomonic, spoken on Gela) and Lengo (SouthEast Solomonic, spoken on Guadalcanal), collected by the author in 2003. From this material comparable body part terms were available for roughly $20 \%$ of the Savosavo terms discussed in this paper. If items are clearly loans from Austronesian languages, or if they are used in neighbouring languages, this is mentioned in the tables in the column 'Additional Information'. ${ }^{1}$ However, note that in cases where the same (identical or very similar) term is only used in Savosavo and some neighbouring languages, but not in languages further away, the direction of borrowing is not always evident. It might have been an original Savosavo term borrowed by the Oceanic languages. Further research and more information on body part terms in other languages is required to distinguish these accounts.

Apart from the terms given below there are nine terms which will not be listed here because they are taboo. ${ }^{2}$ These are three terms for parts of the male genitals (the pubic area, the glans, and the Collum Glandis) and six for parts of the female genitals (the pubic area, the clitoris, the labium, the hymen, the opening of the vulva, and the Paries Anterior Vaginae). None of these terms is a simple body part term. They are all compounds consisting of the general noun referring to the genitals modifying another noun, usually a noun that is not taboo in itself.

\subsection{The face and its parts}

Table 1 lists the 13 body part terms referring to the area corresponding to the English term 'face' (i.e., the front part of the head, including forehead and chin, but excluding ears and head hair) and its parts. Only terms for external parts are listed here. Parts such as 'tongue', 'tooth', etc. are categorised as internal parts of the body and the corresponding terms are listed in Table 3.

The term for 'face', nitonyoko, is a compound consisting of the words nito 'eye' and nyoko 'nose', but it is an exceptional compound because neither of the two components can be said to be modifying the other one (this is very unusual in Savosavo; see discussion of structural properties in Section 3). For most terms used in the Body Colouring Task responses were very consistent across participants, but there was considerable variation in the interpretation of this term: four out of eight participants consistently only coloured eyes and nose, three of them even as unconnected dots (see Fig. 1d and e). Two coloured in a rectangular area from just above the eyes to just below the nose, in one case colouring the full width of the face (Fig. 1b), in the other case stopping right beside the eyes (Fig. 1c). Only the remaining two participants coloured in the area co-extensive with the English term 'face' (Fig. 1a).

The Body Colouring Task was also done for Solomon Islands Pijin, with a group of eight Savosavo speakers different from the ones doing the Savosavo Body Colouring Task.

\footnotetext{
${ }^{1}$ Forms from other languages are given in phonetic transcription (as they are in Tryon and Hackman, 1983).

${ }^{2}$ Only at a safe distance from the speech community did one informant feel comfortable enough to share these terms. As these terms are clearly so sensitive to native speakers I have chosen not to publish them here. In contrast to this the terms for genitals listed in this paper are commonly known terms.
} 
Table 1

The face and its parts

\begin{tabular}{|c|c|c|}
\hline Savosavo term & Translation & Additional information \\
\hline \multicolumn{3}{|l|}{ Simplex } \\
\hline sege & 'forehead' & \\
\hline nito & 'eye’ & \\
\hline nyoko & 'nose' & \\
\hline labe & 'cheek' & \\
\hline napu & 'mouth' & Can also be used for the beak of a bird \\
\hline ngoa & 'lower jaw’ & Lower jaw, including the chin; noe in Lengo, nono in Gela \\
\hline ngolangola & 'facial hair' & $\begin{array}{l}\text { Also used for moustache; pola in the dialects of Ghari, } \\
\text { in Malango and the Poleo dialect of Talise (all South-East } \\
\text { Solomonic, West Guadalcanal; Tryon and } \\
\text { Hackman, 1983, p. 136) }\end{array}$ \\
\hline \multicolumn{3}{|l|}{ Complex } \\
\hline nitonyoko & 'face' & lit. 'eye.nose' \\
\hline nito savusavu & 'eyelid' & lit. 'eye cover' \\
\hline nito isi & 'eyelash' & lit. 'eye ?' \\
\hline nyoko puti & 'nostril' & lit. 'nose hole' \\
\hline nyoko kola & 'bridge of nose' & lit. 'nose stick' \\
\hline napu sebe & 'lip’ & lit. 'mouth lip' \\
\hline
\end{tabular}

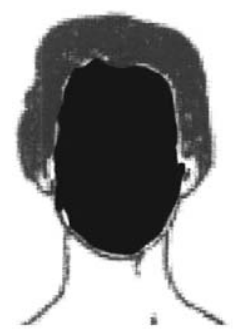

(a)

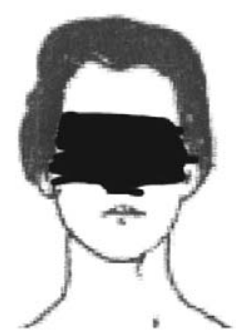

(b)

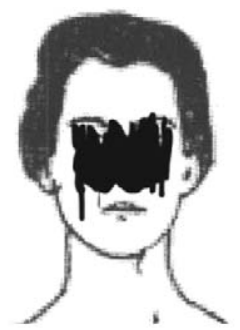

(c)

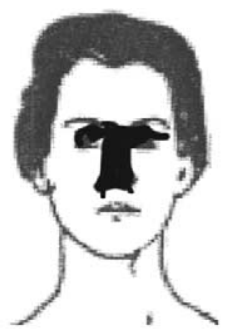

(d)

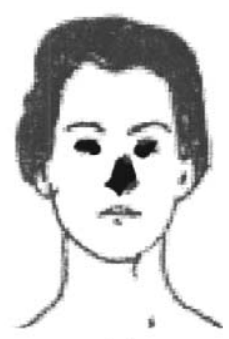

(e)

Fig. 1. Examples of the responses to nitonyoko 'face' in the Body Colouring Task.

Looking at the results for the Solomon Islands Pijin term for face, fes, a response similar to Fig. 1a (but sometimes excluding the forehead) was given by seven participants of the Solomon Islands Pijin Body Colouring Task. The response of the remaining participant was similar to Fig. 1b, but included the mouth. One thing this suggests is that the extension of the Solomon Islands Pijin term fes is based on English 'face'; the extension of nitonyoko, however, is still recognizably based on the literal meaning 'eye.nose'. The two Savosavo speakers responding as shown in Fig. 1a might be an indication that the meaning of nitonyoko is in the process of semantic change due to language contact.

Labe 'cheek' seems to be rarely used. Older speakers are familiar with this term, but one of the two youngest participants of the Body Colouring Task did not recognise it, and the other one was unsure about the meaning, but eventually coloured in the cheek.

\subsection{External parts}

Table 2 lists 37 terms for other external parts of the body. 
The original term for human hair, luta, is almost replaced by sivugha, which originally only referred to animal 'hair', i.e., fur and plumage. Note that neither is used for pubic hair, which is gholo.

There is no word for trunk. Terms referring to parts of the trunk are pika 'belly', tutu sua 'chest', susu 'breast', and lakelake 'shoulder'. The word puzu also refers to part of the trunk, but according to the results of the Body Colouring Task it can mean either 'hip' or 'waist' (see Fig. 2); 6 of 8 participants coloured in more or less of the hips, the remaining two coloured the waist as a narrow strip across the belly.

The terms nato 'leg' and kakau 'arm' are semantically general in that they cover the whole extent of the limb, including hands, feet, fingers and toes. No other term is used to refer to hands or feet, but there is a term for digit and a term for nail. These terms do not distinguish between digits of the arm (i.e., fingers) and digits of the leg (i.e., toes), or between fingernails and toe nails. This is also true for the term referring to the 'big digit', i.e., thumb and big toe. The terms kakau and nato are not ambiguous, i.e., they do not mean 'arm' and 'leg' sometimes and 'hand' and 'foot' at other times. If a speaker says someone broke her kakau, or your kakau is dirty, this could be any part of the arm or the hand apart from the fingers. If it was a broken finger, the more specific term would be used.

Other parts of the limbs that are named are elbow, wrist, and knee. With respect to the legs there are two additional terms that for some informants refer to the upper and lower thigh, namely peghe and kusu sua respectively. However, the results of the Body Colouring Task showed considerable variation in the extension of these terms which could be connected to the taboo status of the upper thigh and the pubic area. These areas are not commonly talked about and have to be covered at all times. When participants coloured in the body part corresponding to peghe, there was some overlap; their responses were all centred around the pubic area (see Fig. 3).

Four participants coloured in this area, including more or less of the lower belly and/or the upper thigh. The other four coloured in the groin, in one case including some of the inner upper thighs. Judging from these responses, peghe roughly refers to the area of the genitals, but has rather general semantics, oscillating between an extended area interpretation (including parts of the upper thigh and/or the lower belly) and a narrower groin interpretation.

Responses to the term kusu sua were less consistent (see Fig. 4). Three participants did not know what the term meant, or were not sure enough to colour anything in. Of the other five, two coloured in roughly the lower half or rather two thirds of the thigh. The areas coloured in by the remaining three participants were all situated on the trunk (see Fig. 5): one coloured in the hips; one a line across the belly, but with an arrow indicating that this part is situated on the back (speakers were shown only a front view of the body); the third person coloured in two dots a bit higher, on both sides of the backbone, again indicating by an arrow that these parts are on the back. Based on this material, the best translation that can be given at present is 'lower thigh', 'area on the lower trunk'. However, taking into account the fact that in this community the pubic area and the upper thigh have to be covered at all times, it is interesting to notice that all responses mark areas immediately adjacent to this sensitive region. ${ }^{3}$

\footnotetext{
${ }^{3}$ Thanks to Nick Enfield for drawing my attention to this.
} 
Table 2

External parts

\begin{tabular}{|c|c|c|}
\hline Savosavo term & Translation & Additional information \\
\hline \multicolumn{3}{|l|}{ Simplex } \\
\hline mijila & 'body' & \\
\hline velavela & 'top of head' & The part of the head one would see when looking down on it \\
\hline batu & 'head' & Austronesian loanword (Tryon and Hackman, 1983, 151f.) \\
\hline sivugha & 'hair, fur, plumage' & $\begin{array}{l}\text { Originally this word was not used for human hair, but now it has } \\
\text { almost replaced the original word luta }\end{array}$ \\
\hline luta & 'human hair' & This is the original word, now almost replaced by sivugha \\
\hline tagalu & ‘ear’ & Austronesian loanword (Tryon and Hackman, 1983, pp. 143-146) \\
\hline tua & 'neck' & \\
\hline ngunguru & 'Adam's apple' & There is also a verb ngurunguru 'to grumble' \\
\hline lakelake & 'shoulder' & \\
\hline kama & 'armpit' & $\begin{array}{l}\text { Can be used as a transitive verb taking an object marking suffix } \\
\text { meaning 'carry something under one's armpit' }\end{array}$ \\
\hline kakau & 'arm' & From the shoulder joint down to and including hand and fingers \\
\hline bulikaku & 'elbow' & \\
\hline seghele & 'wrist' & \\
\hline ririkina & 'digit' & Refers to both finger and toe; ririki in Lengo, ${ }^{n}$ gi ${ }^{n}$ giri in Gela \\
\hline kelekelemuzi & 'nail' & \\
\hline susu & 'breast' & Austronesian loanword (Tryon and Hackman, 1983, pp. 143-145) \\
\hline pika & 'belly' & \\
\hline labu & 'navel' & \\
\hline puzu & 'waist, hip' & $\begin{array}{l}\text { Varying responses in Body Colouring Task, see the discussion } \\
\text { in Section } 2.2\end{array}$ \\
\hline potopoto & 'back' & From the neck down to and including the buttocks \\
\hline gholo & 'pubic hair' & \\
\hline kai & 'vulva' & \\
\hline koghe & ‘penis’ & This term is sometimes used as a swearword \\
\hline boro & 'buttock'a & \\
\hline vezi & 'anus' & \\
\hline nato & 'leg' & From the hip bone down to and including foot and toes \\
\hline peghe & $\begin{array}{l}\text { 'upper thigh, } \\
\text { wider pubic area' }\end{array}$ & $\begin{array}{l}\text { Varying responses in the Body Colouring Task, see the } \\
\text { discussion in Section } 2.2\end{array}$ \\
\hline tuturinga & 'knee' & $\begin{array}{l}\text { tuturu, tutumu, tuпutumu or similar forms in several languages } \\
\text { (Tryon and Hackman, 1983, pp. 151-153) }\end{array}$ \\
\hline \multicolumn{3}{|l|}{ Complex } \\
\hline korakora & 'skin' & $\begin{array}{l}\text { Skin of humans or animals; can also be used for the bark of a tree; } \\
\text { koksra or kokora in languages of North-West Guadalcanal } \\
\text { (South-East Solomonic), koreksre in Marovo (Meso-Melanesian, } \\
\text { New Georgia; Tryon and Hackman, 1983, 159f.) }\end{array}$ \\
\hline tagalu puti & 'ear opening' & lit. 'ear hole' \\
\hline tagalu bogho & 'earlobe' & lit. 'ear?' \\
\hline ngai ririkina & 'thumb, big toe' & lit. 'big digit' \\
\hline tutu sua & 'chest' & lit. '[a type of basket] Att.m' \\
\hline susu kuakua & 'nipple' & lit. 'breast?' \\
\hline (koghe) bogho & 'scrotum' & $\begin{array}{l}\text { lit. '(penis) ?'; sometimes only the second noun is used to refer } \\
\text { to 'scrotum' }\end{array}$ \\
\hline kusu sua & $\begin{array}{l}\text { 'lower thigh', 'area } \\
\text { on the lower trunk' }\end{array}$ & $\begin{array}{l}\text { lit. '? Att.m'; varying responses in the Body Colouring Task, } \\
\text { see the discussion in Section } 2.2\end{array}$ \\
\hline garogaro & 'side of the body' & lit. 'Dup-thin' \\
\hline
\end{tabular}

${ }^{a}$ An anonymous reviewer suggested that this is a possible Austronesian loan. 


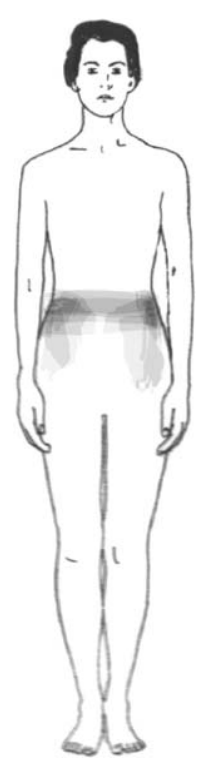

Fig. 2. The superimposed responses to puzu 'waist, hip'. These pictures were obtained by laying all responses to a term on top of each other; the darker an area is shaded, the more participants coloured it in.

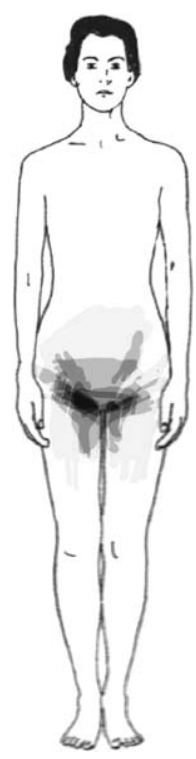

Fig. 3. The superimposed responses to peghe 'upper thigh, wider pubic area'.

The responses to kusu sua that are located on the trunk are in the area normally referred to by puzu 'waist, hip' (see Figs. 2 and 4). Comparing what these participants coloured in as the figure's puzu shows that the answers were complementary (see Fig. 5): the first participant, colouring in the hips for kusu sua, coloured in the waist for puzu. The second and 


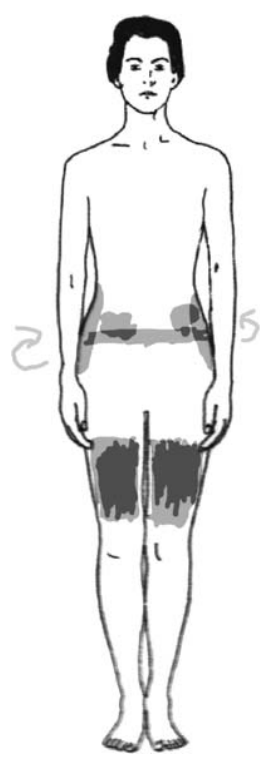

Fig. 4. The superimposed responses to kusu sua 'lower thigh', 'area on the lower trunk'.

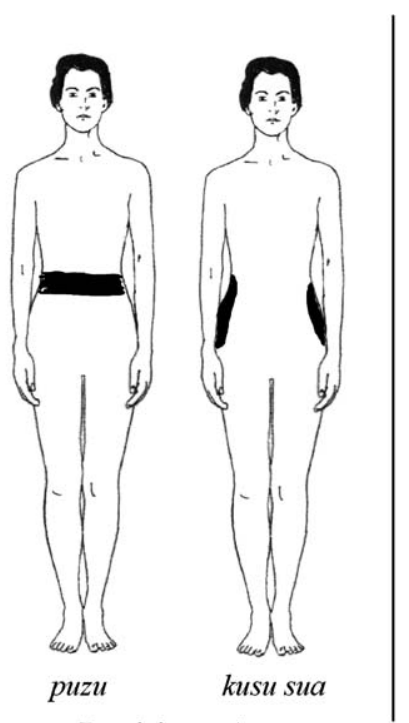

Participant 1

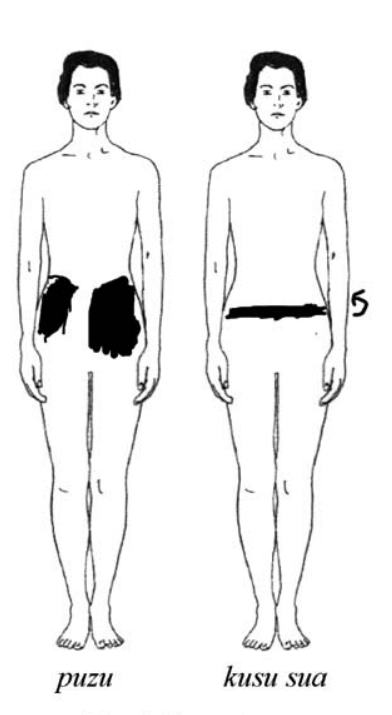

Participant 2

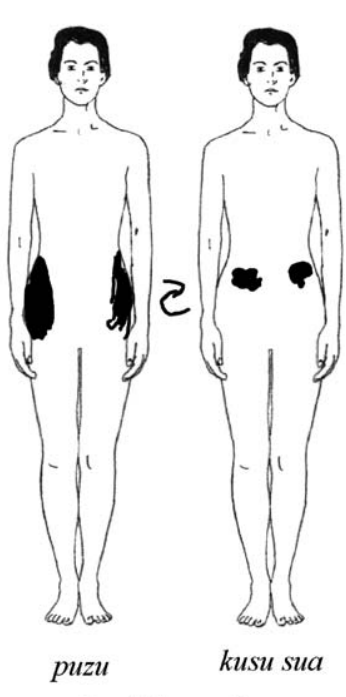

Participant 3

Fig. 5. Comparing the responses to puzu 'waist, hip' and kusu sua 'lower thigh', 'area on the lower trunk' for three participants.

third participants both indicated that kusu sua was located in the dorsal area of the waist. When responding to the term puzu, they both coloured in the hips. 
This suggests that the responses to these two terms were not independent. Puzu was always asked first, ${ }^{4}$ and no matter which response was given for puzu, waist or hip, the response to kusu sua was surprisingly similar to the opposite interpretation; when puzu was interpreted as waist, the hips were coloured in for kusu sua, and vice versa. Since the responses to $p u z u$ were more uniform than the responses to kusu sua, and given the fact that some participants did not know the latter term at all, it might be the case that these three participants were not sure about the exact meaning of kusu sua, but decided to colour in an area that was at least not inconsistent with their former responses to other terms.

The reason for the varying responses to these terms is not known at present, but the fact mentioned above, that peghe 'upper thigh, wider pubic area' and kusu sua 'lower thigh', 'area on the lower trunk' are rarely used in everyday speech, could be part of the answer.

\subsection{Internal parts}

In Table 3, 27 terms for internal parts of the body (organs, body fluids, bones, muscles, etc.) are given.

The term for heart, kidi puruma, is a metaphorical description. The literal translation would be 'fruit.of.Kokoilo.tree bottle', thus describing the heart as a container shaped like the fruit of a Kokoilo tree.

There are two ways to refer to the womb; one is valedale, a word that according to an informant is a loanword from Ghari (South-East Solomonic, spoken on West Guadalcanal; lit. "child house ${ }^{5}$ ), an Austronesian equivalent to the other one, the metaphorical expression nyuba tuvi (lit. 'child house').

\subsection{Other terms}

Table 4 gives 10 terms which clearly belong to the body domain but do not fit in one of the previous categories. These include terms for body products such as mimi 'urine' and nyoro 'snot', the word for wound, tubu, and one configurational term, karakarabizi 'fist'.

\subsection{Animal body part terms}

Most of the terms given in the tables above can be used to refer to the analogous parts of the body of an animal. However, the mapping is not always self-evident. For example, when referring to the claws of a cat, ririkina 'digit' is used, not kelekelemuzi 'fingernail', 'toe nail', although the latter would correspond more closely as far as anatomy, function and consistency is concerned. Eleven special terms used only for body parts of animals are given in Table 5 .

\footnotetext{
${ }^{4}$ Puzu was one of the 15 terms that formed the core for the Body Colouring Task. These terms were randomised and appeared twice. Kusu sua and two other terms (peghe 'upper thigh, wider pubic area' and lakelake 'shoulder') were added to the end of the task post-hoc to find out more about their semantics.

5 Thanks to the anonymous reviewers for pointing this out.
} 
Table 3

Internal parts

\begin{tabular}{|c|c|c|}
\hline Savosavo term & Translation & Additional information \\
\hline \multicolumn{3}{|l|}{ Simplex } \\
\hline kineghe & 'brain' & \\
\hline lapi & 'tongue' & $\begin{array}{l}\text { lapi in Gela, some languages Guadalcanal } \\
\text { (South-East Solomonic) and lapi, glapi or ðapi in some } \\
\text { languages of St. Ysabel (mostly Meso-Melanesian, } \\
\text { one South-East Solomonic; Tryon and Hackman, 1983, p. 164) }\end{array}$ \\
\hline тити & 'gum' & \\
\hline nale & 'tooth' & $\begin{array}{l}\text { nane or nāne in Touo (or Mbaniata, Papuan, Rendova Island; } \\
\text { Tryon and Hackman, 1983, p. 163; Dunn and Terrill, pers. com.) }\end{array}$ \\
\hline tave & 'throat' & $\begin{array}{l}\text { Considered as the place of emotions; often used metaphorically } \\
\text { for things to do with emotions, voice and memory, e.g., to express } \\
\text { that someone forgot something one would say 'his/her throat was } \\
\text { shut' }\end{array}$ \\
\hline kalakala & 'liver' & \\
\hline tutupogha & 'kidney' & \\
\hline boli & 'intestines' & \\
\hline mimi & 'bladder' & $\begin{array}{l}\text { Also refers to 'urine' (cf. Table 4) and can be used as a verb meaning } \\
\text { 'to urinate'; Austronesian loanword (at least for the verb meaning; } \\
\text { Tryon and Hackman, 1983, pp. 439-442) }\end{array}$ \\
\hline valedale & 'womb' & $\begin{array}{l}\text { According to the informant loanword from a Guadalcanal language, } \\
\text { lit. 'child house' }\end{array}$ \\
\hline bakabakala & 'kneecap' & \\
\hline tovolo & 'bone' & \\
\hline totoro & 'muscle' & \\
\hline ghabu & 'blood' & $\begin{array}{l}\text { ravu in Lavukaleve (Papuan, Russell Islands; Terrill, this volume), } \\
\gamma a^{m} b u, h a^{m} b u \text { or slightly different forms in most South-East } \\
\text { Solomonic languages (Tryon and Hackman, 1983, 140f.) }\end{array}$ \\
\hline ula & 'vein'a & \\
\hline seregha & 'fat' & \\
\hline \multicolumn{3}{|l|}{ Complex } \\
\hline suasua & 'lungs' & $\begin{array}{l}\text { Also refers to 'saliva' (cf. Table 4) and can be used as a verb meaning } \\
\text { 'to spit' }\end{array}$ \\
\hline melomelo & 'flesh' & \\
\hline zaravua nale & 'wisdom tooth' & $\begin{array}{l}\text { lit. ' }+/-7 \text {.generations tooth'; zaravua is a reciprocal kinship term } \\
\text { referring to relatives that are seven generations apart from ego } \\
\text { in both directions; there is no term for relatives beyond } \\
+/-7 \text { generations. }\end{array}$ \\
\hline tuvi tovolo & 'collarbone' & lit. 'house bone' \\
\hline tina tovolo & 'backbone' & lit. '? bone' \\
\hline kidi puruma & 'heart' & $\begin{array}{l}\text { lit. 'fruit.of.Kokoilo.tree bottle'; but note that older wordlists } \\
\text { give kidopuruma (Todd, 1977, p. 834) and } k i^{n} \text { dopurama } \\
\text { (Tryon and Hackman, 1983, p. 151) }\end{array}$ \\
\hline tavetave & 'windpipe, gullet' & lit. 'DUP-throat' \\
\hline nyuba tuvi & 'womb' & lit. 'child house' \\
\hline bogho kato & 'testicle' & lit. '? stone' \\
\hline vezi gonogono & 'rectum' & Connection between intestines and anus; lit. 'anus ?' \\
\hline ula totoro & $\begin{array}{l}\text { 'muscles of upper } \\
\text { arm or thigh' }\end{array}$ & lit. 'vein muscle' \\
\hline
\end{tabular}

a An anonymous reviewer suggested that this is an Austronesian loan. 
Table 4

Other terms

\begin{tabular}{|c|c|c|}
\hline Savosavo term & Translation & Additional information \\
\hline \multicolumn{3}{|l|}{ Simplex } \\
\hline nyoro & 'snot' & \\
\hline mumuta & 'vomit' & $\begin{array}{l}\text { This term can also be used as a verb meaning 'to vomit'; } \\
\text { in Lavukaleve (Papuan) 'to vomit' is mumut (Terrill, this volume), } \\
\text { in some Meso-Melanesian and South-East Solomonic languages muta, } \\
\text { mutamuta or mumuta or similar forms } \\
(\text { Tryon and Hackman, } 1983 \text {, pp. } 440-441)^{\text {a }}\end{array}$ \\
\hline mimi & 'urine' & $\begin{array}{l}\text { Also refers to 'bladder' (cf. Table } 3 \text { ) and can be used as a verb meaning } \\
\text { 'to urinate'; Austronesian loanword (at least for the verb meaning; } \\
\text { Tryon and Hackman, } 1983 \text {, pp. 439-442) }\end{array}$ \\
\hline zugha & 'faeces' & \\
\hline kapa & 'sperm’ & \\
\hline kinokino & 'sweat' & This term can be used as a verb meaning 'to sweat' \\
\hline buluta & 'pus' & \\
\hline tubu & 'wound' & \\
\hline karakarabizi & 'fist' & This term is not known to all speakers \\
\hline \multicolumn{3}{|l|}{ Complex } \\
\hline suasua & 'saliva' & Also refers to 'lungs' (cf. Table 3 ) and can be used as a verb meaning 'to spit' \\
\hline
\end{tabular}

a An anonymous reviewer suggested that this is a possible Austronesian loan.

Table 5

Animal body part terms

\begin{tabular}{|c|c|c|}
\hline Savosavo term & Translation & Additional information \\
\hline \multicolumn{3}{|l|}{ Simplex } \\
\hline nyokinyoki & 'pig snout' & Compare nyoko 'nose', Table 1 \\
\hline ghavara & ‘wing' & \\
\hline kodo & 'tail' & Can be used for dogs, fish, etc. \\
\hline savea & 'side fin' & \\
\hline kudia & 'back fin' & \\
\hline abeabe & 'back fin of a shark' & \\
\hline vola & 'shed snake skin' & \\
\hline kato & 'stomach of poultry' & Refers to the internal organ only; kato normally means 'stone' \\
\hline si & 'egg’ & Of all animals but Megapode birds \\
\hline kolei & 'Megapode egg' & \\
\hline \multicolumn{3}{|l|}{ Complex } \\
\hline malamalabo sua & 'hoof' & $\begin{array}{l}\text { lit. 'Dup-footprint Att.m'; used for the hooves of a cow; } \\
\text { not clear if it can refer to feet of other animals as well }\end{array}$ \\
\hline
\end{tabular}

\section{Structure of savosavo body part terms}

This section describes in more detail the morphosyntactic structure of the 97 body part terms listed in this paper. More than two thirds of them (70) are simplex expressions, i.e., they are synchronically not analyzable. This includes 17 words that exhibit reduplicative 
patterns used in Savosavo but whose postulated stems are not in use at present. ${ }^{6}$ The remaining 27 words are complex expressions, analyzable forms of different kinds. One is an expression consisting of a noun modified by an adjective (ngai ririkina 'thumb, big toe', lit. 'big digit'). Structurally this expression cannot be distinguished from an ordinary NP meaning 'big digit', but it is nevertheless treated here as a body part term, since it normally refers to someone's thumb or big toe if used in a possessive construction, for instance lova ngai ririkina 'his thumb/big toe'. The other complex terms are reduplications of existing words (5), attributive constructions (3), and compounds (18). In the remainder of this section each of these is discussed in more detail.

\subsection{Reduplications}

Reduplication is always word initial; the first one or two syllables of the stem are copied and prefixed. It is used for a wide range of operations, derivational (e.g., deriving nouns from verb stems or other nouns, and intransitive verb stems from transitive verb stems) as well as inflectional (e.g., iterative aspect on verbs).

As mentioned above, the postulated stems of most of the reduplicated body part terms are not in use at present. However, the remaining reduplicated terms that are decomposable in present day Savosavo are listed below:

$\begin{array}{llll}\text { 1. } & \text { garogaro 'side of the body' } & \text { garo (adj) } & \text { 'thin' } \\ \text { 2. } \begin{array}{ll}\text { tavetave } \\ \text { 3. }\end{array} \text { korakora } & \text { 'skindpipe, gullet' } & \begin{array}{l}\text { tave }(\mathrm{n}) \\ \text { kora- }(\mathrm{v})\end{array} & \text { 'throat' } \\ \text { 'to skin or peel sth.' }\end{array}$

For two other reduplicated terms (melomelo 'flesh' and suasua 'lungs', 'saliva') corresponding unreduplicated forms exist: the noun melo 'tuna', the noun sua 'devilman', the transitive verb sua- 'to take something off', and the particle sua 'attributive marker (m)'. It is unclear at present whether these forms are related.

\subsection{Attributive constructions}

Attributive constructions consist of an element $X$ (a verb, numeral, noun or noun phrase) and the attributive marker. By adding this marker to an element $X$ one can derive nominal expressions meaning 'something or someone characterised by $\mathrm{X}$ ' (see examples (1) and $\left.(2)^{7}\right)$. There is a paradigm of different forms for singular masculine, singular feminine, dual and plural. Among other things this helps to distinguish the third person singular masculine form sua from the other two homophonic stems mentioned in Section 3.1.

\footnotetext{
${ }^{6}$ One term of this group is ngolangola 'facial hair'. It is formally reduplicated, but a word ngola has not been documented in modern Savosavo; however, the word for beard in the dialects of Ghari, in Malango and the Poleo dialect of Talise (all SES languages, spoken on West Guadalcanal) is ngola (Tryon and Hackman, 1983, p. 136). So it could have been borrowed in reduplicated form, or reduplicated later by Savosavo speakers.

${ }^{7}$ For key to abbreviations see Appendix.
} 

(1) bo soma
go Att.f 'the one (f) going, the one (f) who went'
(2) ite sua
be.true Att.m 'something true'

The three body part terms derived in this manner are tutu sua 'chest' (lit. '[a type of basket] Att.m', i.e., 'something basket-like'), ${ }^{8}$ kusu sua 'lower thigh', 'area on the lower trunk' (lit. '? Att.m'), and malamalabo sua 'hoof' (lit. 'Dup-footprint Att.m', i.e., 'something footprint-like').

\subsection{Compounds}

Compounds in Savosavo are right headed constructions. In compounds referring to parts of the body, the head and/or the modifying noun can be a body part term. ${ }^{9}$ The compounds referring to a part of the body listed in this paper exemplify all four possibilities:

1. If only the modifying noun is a body part term the resulting compound refers to a feature associated with that body part, as can be seen in the compound nyoko kola 'bridge of nose' (lit. 'nose stick'). Most of the compounds listed in this paper (11 out of 18) are of this kind. It could be argued that these compounds express partonomic relations between the body part term referred to by the modifying noun and the one referred to by the compound; but this does not seem to be the case, as becomes clear in the discussion below.

2. If the head noun is a body part term it is a generic term. The compound then refers to a specific referent of this superordinate term, i.e., there is a taxonomic relation between the head noun and the resulting compound. There are three examples of this in the list given above: tuvi tovolo 'collarbone' (lit. 'house bone'), tina tovolo 'backbone' (lit. '? bone' ${ }^{10}$ ), and zaravua nale 'wisdom tooth' (lit. '+/-7.generations tooth').

3. If both nouns are body part terms the resulting compound also expresses a taxonomic relation. The only example in this paper is ula totoro 'muscles of upper arm or thigh' (lit. 'vein muscle').

4. If neither the head nor the modifying noun is a body part term the resulting compound is a metaphoric body part term. Two compounds of this kind are listed above, nyuba tuvi 'womb' (lit. 'child house'), and kidi puruma 'heart' (lit. 'fruit.of.Kokoilo.tree

\footnotetext{
${ }^{8}$ For this term one could suggest a connection with the reduplicated term suasua 'lungs'; sua could be interpreted as being the (today obsolete) stem from which suasua was once derived, that had a similar meaning as the reduplicated term. Tutu sua could then be seen as a compound referring to the basket containing the lungs (thanks to Miriam van Staden for drawing my attention to this). However, if this were the case then the order of the nouns would be reversed (sua tutu), so that sua, as the modifying noun, would specify the kind of basket (tutu) that is referred to by the compound.

${ }^{9}$ Note, however, that not every compound that includes a body part term necessarily refers to a part of the body, e.g., molo napu 'cutting edge of a knife (lit. 'knife mouth').

10 The word tina is the term for 'body' in neighbouring Lavukaleve (Terrill, this volume); if this term was borrowed, tina tovolo 'backbone' could be translated literally as 'body bone'. According to one anonymous reviewer tina could be from Proto-Oceanic *tina 'mother', sometimes used to mean 'big, important'. The literal translation of tina tovolo would then be 'big/important bone'.
} 
bottle'). In contrast to the compounds described in 1 and 2, these compounds have no partonomic or taxonomic implications within the body domain, but they refer to a certain kind of house and a bottle of a specific form respectively.

The complex form nitonyoko 'face' (lit. 'eye.nose'), which is a compound in the sense that it consists of two nouns, is a special case in that it is impossible to say that one noun is modifying the other in any way. Since there is evidence that the compound carries only one primary stress it will be treated as one word.

Those compounds that consist of a body part term modifying a noun that is not a body part term (e.g., nyoko kola 'bridge of nose' (lit. 'nose stick')) are interpreted as referring to features of the body part denoted by the modifying noun. The term 'features' is used to avoid talking about 'parts' of body parts, which would suggest partonomic relations. However, there is no linguistic evidence that these features are seen as being in a partwhole relationship with the respective body part. The existence of these compounds itself is no evidence for a partonomic relation between the body part referred to by one of the nouns of a compound and the body part referred to by that compound. ${ }^{11}$ They can equally be interpreted as providing locational or taxonomic instead of partonomic information: the term nyoko puti 'nostril' (lit. 'nose hole'), refers to a kind of hole, namely one that is located at the nose.

So is there any linguistic evidence for a conceptual part-whole relation between body parts in Savosavo? There is no documented word for 'part' or 'body part' in Savosavo, nor is there a construction conveying that relationship, therefore there is no straightforward way of saying ' $\mathrm{X}$ is part of $\mathrm{Y}$ '. Furthermore speakers object to constructions in which one body part is possessed by another body part or the term for body, mijila. It is, however, possible to use the possessive construction for people and their body parts, although there is no evidence that these constructions express anything more than an ownership relation:

$\begin{array}{llll}\text { lo } & \text { mapa } & \text { lo-va } & \text { batu } \\ \text { Art } & \text { Person } & \text { 3Sgm-Possm } & \text { head 'the man's head' }\end{array}$

The only way one can relate two body part terms to each other would be with a general locative construction of the following kind:

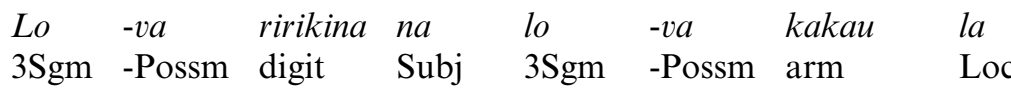

'His finger is on his arm'

(7) Lo -va nyoko na lo -va nitonyoko la

3Sgm -Possm nose Subj 3Sgm -Possm face Loc

'His nose is on his face'

(8) Lo nyoko na napu taghata

Art nose Subj mouth above.Loc

'The nose is above the mouth'

$\overline{11}$ In his discussion of Jahai compounds Burenhult (this volume) argues along similar lines. 
Summing up, no evidence for a part-whole relation between body parts in Savosavo emerges from the linguistic data. That one body part cannot possess another body part in fact could be seen as evidence against it. There is also no evidence that the body part terminology of Savosavo could be structured hierarchically as suggested by Andersen (1978, p. 335); see also Brown (1976): "This domain tends to be organised into a hierarchical structure with five (or occasionally six) levels". There is no language-internal basis for constructing a multi-layered hierarchy of this kind. If it could be shown that there is a conceptual part-whole relationship the fact that the body, mijila, cannot possess any other body part (in contrast to mapa 'person') would suggest that in Savosavo the 'person', not the 'body', is the prototypical whole with respect to the body part domain, an idea expressed and argued for by Harvey (1996, p. 117). This would lead to a hierarchy with two levels only, the 'person' on the first level, and all other body parts at the second. This and the structural possibilities of relating two body parts to each other demonstrated above suggest that in the Savosavo body part domain spatial relations are more central than partonomic and taxonomic relations. ${ }^{12}$

\section{Acknowledgements}

The research for this paper was funded by the Max Planck Society, in association the ESF OMLL programme. I am grateful to the people of Savo Island for their hospitality and cooperation, and I would like to thank the participants of the Body Colouring Task as well as all those who provided the spontaneous and elicited data this paper is based on. Furthermore thanks to Alex Dukers for processing the Body Colouring Task data, and Niclas Burenhult, Nick Enfield, Asifa Majid, Stuart Robinson, Miriam van Staden, Angela Terrill and two anonymous reviewers for helpful comments.

\section{Appendix}

\section{Abbreviations}

$\begin{array}{ll}3 & \text { third person } \\ \text { Art } & \text { definite article } \\ \text { Att } & \text { attributive marker } \\ \text { f } & \text { feminine } \\ \text { Loc } & \text { locational } \\ \text { m } & \text { masculine } \\ \text { Poss } & \text { possessive } \\ \text { Sg } & \text { singular } \\ \text { Subj } & \text { subject marking }\end{array}$

In the orthography used in this paper most graphemes correspond to the respective phonetic symbols except: $j$ (palatal voiced stop), $n y$ (palatal nasal); $n g$ (velar nasal), and gh (velar approximant).

\footnotetext{
${ }^{12}$ See Palmer and Nicodemus (1985) for another example of a language in which spatial relations are very important in the body domain (Coeur d'Alene, Interior Salish, spoken in the USA).
} 


\section{References}

Andersen, E.S., 1978. Lexical universals of body-part terminology. In: Greenberg, J.H. (Ed.), Universals of Human Language, Word Structure, vol. 3. Stanford University Press, Stanford, pp. 335-368.

Brown, C.H., 1976. General principles of human anatomical partonomy and speculations on the growth of partonomic nomenclature. American Ethnologist 3, 400-424.

Burenhult, N., this volume. Body part terms in Jahai. In: Majid, A., Enfield, N.J., van Staden, M. (Eds.), Parts of The Body: Cross-Linguistic Categorisation. Special Issue of Language Sciences, doi:10.1016/ j.langsci.2005.11.002.

Dunn, M., Reesink, G., Terrill, A., 2002. The East Papuan Languages: A Preliminary Typological Appraisal. Oceanic Linguistics 41, 28-62.

Enfield, N.J., this volume. Elicitation guide on parts of the body. In: Majid, A., Enfield, N.J., van Staden, M. (Eds.), Parts of The Body: Cross-Linguistic Categorisation. Special Issue of Language Sciences, doi:10.1016/ j.langsci.2005.11.003.

Foley, W.A., 1986. The Papuan Languages of New Guinea. Cambridge University Press, Cambridge.

Harvey, M., 1996. Body parts in Warray. In: Chappell, H., McGregor, W. (Eds.), The Grammar of Inalienability: A Typological Perspective on Body Part Terms and The Part-Whole Relation. Mouton de Gruyter, Berlin, pp. 111-153.

Palmer, G.B., Nicodemus, L., 1985. Coeur d'Alene Exceptions to Proposed Universals of Anatomical Nomenclature. American Ethnologist 12, 341-359.

Ross, M.D., 1988. Proto Oceanic and the Austronesian Languages of Western Melanesia. Pacific Linguistics C-98, Canberra.

Terrill, A., 2002. Systems of nominal classification in East Papuan languages. Oceanic Linguistics 41, 63-88.

Terrill, A., this volume. Body part terms in Lavukaleve, A Papuan Language of the Solomon Islands. In: Majid, A., Enfield, N.J., van Staden, M. (Eds.), Parts of The Body: Cross-Linguistic Categorisation. Special Issue of Language Sciences, doi:10.1016/j.langsci.2005.11.008.

Todd, E.M., 1977. The Solomon Language Family. In: Wurm, S.A. (Ed.), New Guinea Area Languages and Language Study: Papuan Languages and The New Guinea Linguistic Scene, vol. 1., Reprint. Pacific Linguistics C-38, Canberra, pp. 805-846.

Tryon, D.T., Hackman, B.D., 1983. Solomon Islands Languages: An Internal Classification. Pacific Linguistics C-72, Canberra.

van Staden, M., Majid, A., this volume. Body colouring task. In: Majid, A., Enfield, N.J., van Staden, M. (Eds.), Parts of The Body: Cross-Linguistic Categorisation. Special Issue of Language Sciences, doi:10.1016/ j.langsci.2005.11.004.

Wegener, C., in preparation. Aspects of The Grammar of Savosavo. 